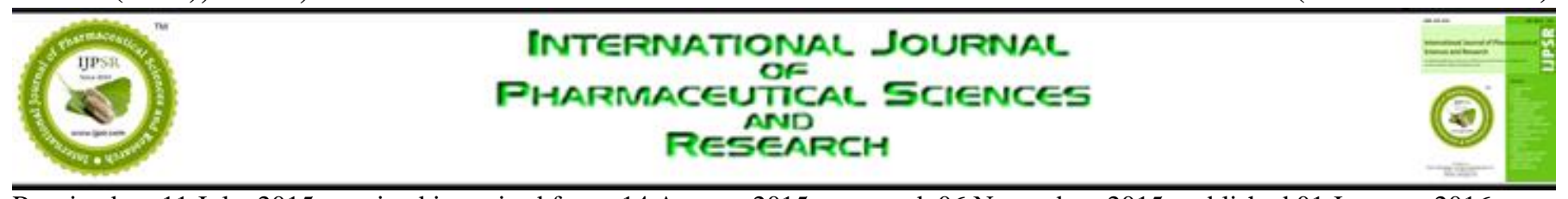

Received on 11 July, 2015; received in revised form, 14 August, 2015; accepted, 06 November, 2015; published 01 January, 2016

\title{
SYNTHESIS, PHYSICO-CHEMICAL INVESTIGATIONS AND BIOLOGICAL SCREENING OF METAL (II) COMPLEXES WITH HYDRAZONE SCHIFF BASE DERIVED FROM 5-FLUORO- 3-HYDRAZONOINDOLIN-2-ONE AND ISOPHTHALALDEHYDE
}

\author{
K. Siddappa* and M. Nabiya Sultana
}

Department of Studies and Research in Chemistry, Gulbarga University, 585106 Gulbarga, Karnataka, India.

\section{Keywords:}

Schiff base, Metal complexes, Spectral studies, Antimicrobial activity and DNA cleavage.

\section{Correspondence to Author:}

K. Siddappa

Department of Studies and Research in Chemistry, Gulbarga University, 585106 Gulbarga, Karnataka, India.

E-mail: siddappa_65@rediffmail.com

\begin{abstract}
New tetradentate Schiff base and its $\mathrm{Co}(\mathrm{II}), \mathrm{Ni}(\mathrm{II}), \mathrm{Cu}(\mathrm{II})$, $\mathrm{Zn}(\mathrm{II}), \mathrm{Cd}(\mathrm{II})$ and $\mathrm{Hg}$ (II) complexes formed by the condensation of 5-fluoro3-hydrazonoindolin-2-one with isophthalaldehyde. The coloured complexes were prepared of $\left[\mathrm{MLX}_{2}\right]$, Where $\mathrm{L}=$ Schiff base hydrazone, $\mathrm{M}=\mathrm{Co}(\mathrm{II})$, $\mathrm{Ni}(\mathrm{II}), \mathrm{Cu}(\mathrm{II}), \mathrm{Zn}(\mathrm{II}), \mathrm{Cd}(\mathrm{II})$ and $\mathrm{Hg}(\mathrm{II}), \mathrm{X}=\mathrm{Cl}-$. Physico-chemical characterization has been carried out to determine the structure of the complexes. All the synthesized compounds, were studied for their in vitro antibacterial, and antifungal activities, against two Gram-negative (Shigella flexneri and Enterococcus aerogens) and one Gram-positive (Micrococcus luteus,) bacterial strains and against three fungal strains (Candida krusiae Candida parasilopsis and Malassesia pachydermatis) by using cup-plate method. The DNA cleavage capacity of all the complexes was analysed by agarose gel electrophoresis method.
\end{abstract}

INTRODUCTION: The development of bioinorganic chemistry field has increased the interest in Schiff base complexes, as they may serve as models for biologically important compounds and bioinorganic processes. Biological activity of complexes derived from hydrazones has been widely studied and found to have numerous biological activities: antibacterial, antitumor, antimalarial and antituberculosis effects. ${ }^{1}$ Schiff bases are a significant group of organic compounds that have biological activities and diverse applications because of their antibacterial, antivirus activities, metal complexation and other pharmacological effects.

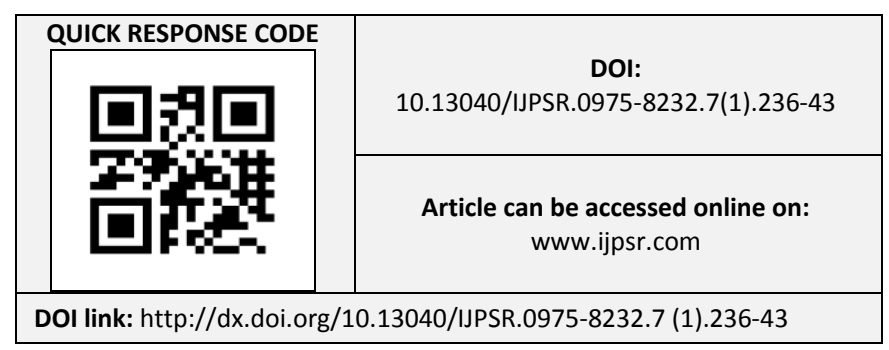

In recent years, Schiff bases and their complexes were established to have significant antitumor and biological activity. ${ }^{2}$ Schiff base containing more than one hetero atoms beside $\pi$-electrons exhibit high inhibiting properties by providing electrons to interact with metal surface. ${ }^{3}$ In this paper we report the preparation and structural characterization and biological screening of hydrazone Schiff base derived from 5-fluoro-3-hydrazonoindolin-2-one and isophthalaldehyde and its metal (II) complexes.

\section{Experimental:}

All the starting chemicals and solvents were of analytical grade and used without further purification. The hydrated metal salts were obtained from Loba.

\section{Synthesis of Schiff base ligand:}

0.002 mol, solution of 5-fluoro-3hydrazonoindolin-2-one was added to $0.001 \mathrm{~mol}$, solution of isophthalaldehyde in methanol, after addition reaction mixture is heated under reflux for 
about 6-7 hours at $70^{\circ} \mathrm{C}$. After completion of reaction precipitate of ligand was formed. The product filtere after cooling and purified with methanol to afford Schiff base ligand as shown in Fig. 1. The purity of ligand was checked by M. P. and TLC.

\section{Synthesis of metal complexes:}

Metal complexes of Schiff base were prepared by mixing $1 \mathrm{mmol}$ of Schiff base with $1 \mathrm{mmol}$ of $\mathrm{Co}(\mathrm{II}), \mathrm{Ni}(\mathrm{II}), \mathrm{Cu}(\mathrm{II}), \mathrm{Zn}$ (II), $\mathrm{Cd}$ (II) and $\mathrm{Hg}$ (II) salts keeping ligand-metal ratio $1: 1$. The resultant mixture was than refluxed for 2-3 hours. Then, to the reaction mixture sodium acetate was added to adjust the $\mathrm{pH}$ to 6.0-7.0. The complex obtained in each time was cooled, filtered and washed with the ethanol many times to purify and removed the excess of ligand. Finally complexes were places in desiccators for drying. ${ }^{4}$

\section{Analytical Methods:}

Elemental analysis carbon, hydrogen and nitrogen analysis was carried out using a Heracus Carlo Erba $1108 \mathrm{CHN}$ analyzer at STIC, Cochin. The IR spectra of the Schiff base and its $\mathrm{Co}(\mathrm{II}), \mathrm{Ni}(\mathrm{II})$, $\mathrm{Cu}$ (II), $\mathrm{Zn}$ (II), $\mathrm{Cd}(\mathrm{II})$ and $\mathrm{Hg}(\mathrm{II})$ complexes were recorded in the region of $4000-250 \mathrm{~cm}^{-1}$ on a Perkin Elmer - Spectrum RX-IFTIR spectrophotometer. The electronic spectra of the $\mathrm{Co}(\mathrm{II}), \mathrm{Ni}$ (II) and $\mathrm{Cu}$ (II) complexes were recorded on an ELICO SL-164 double beam UV-visible spectrophotometer in the range of $200-900 \mathrm{~nm}$ in DMF $\left(10^{-3} \mathrm{M}\right)$ solution. Magnetic susceptibility measurements were made at room temperature on a Gouy balance using $\mathrm{Hg}\left[\mathrm{Co}(\mathrm{NCS})_{4}\right]$ as the calibrant.

Molar conductivity measurements were recorded on an ELICO CM-180 conductivity bridge in DMF solution $\left(10^{-3} \mathrm{M}\right)$ using a dip-type conductivity cell fitted with a platinum electrode, The ${ }^{1} \mathrm{H}-\mathrm{NMR}$ spectra were recorded in DMSO- $\mathrm{d}_{6}$ on a Bruker $500 \mathrm{MHz}$ spectrophotometer using TMS as an internal standard. The mass spectra were recorded on a JEOL GC mate mass spectrophotometer. The ESR spectrum of the $\mathrm{Cu}$ (II) complex in the polycrystalline state was recorded on a Varian-E4X band EPR spectrophotometer using TCNE as the ' $\mathrm{g}$ 'marker $(\mathrm{g}=2.00277)$ at room temperature. The XRD patterns of the ligand and its $\mathrm{Cu}$ (II) complex were recorded on a Rigaku $D_{\max } \mathrm{X}$-ray diffractometer using $\mathrm{Cu} \mathrm{K} \alpha=1.5404$ radiation $(\lambda$ $\mathrm{A}^{\circ}$ ).

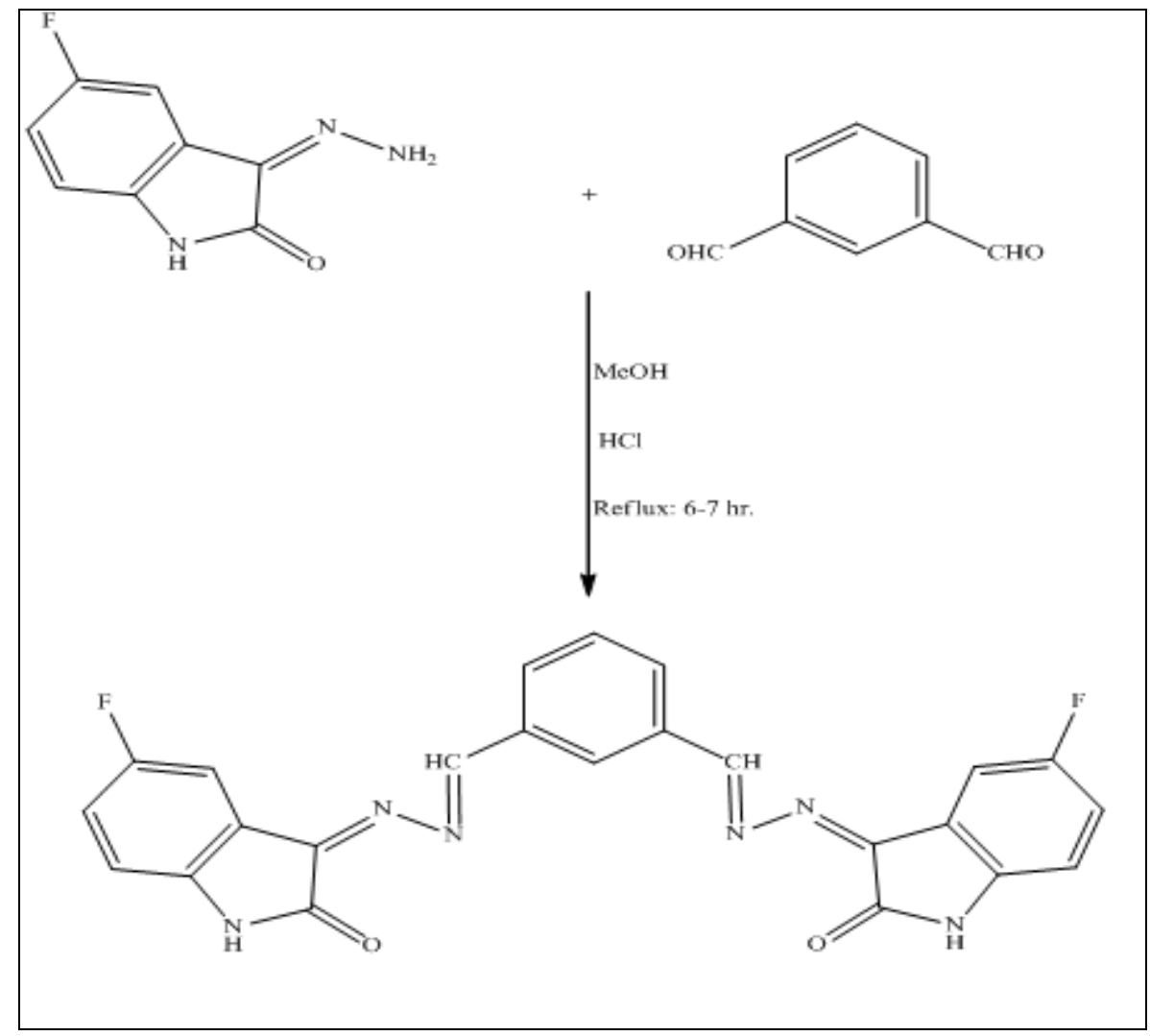

FIG. 1: SCHEMATIC REPRESENTATION OF SCHIFF BASE 


\section{Antimicrobial assay:}

The synthesized compounds were evaluated for their antimicrobial activity against Gram positive bacterial strain, Micrococcus luteus, Gram negative bacterial strains, Shigella flexneri and Enterococcus aerogens and three fungal strains, Candida krusiae, Candida parasilopsis and Malassesia pachydermatis by cup-plate method. ${ }^{5}$ Standard antibacterial drug (Ampicillin) and antifungal drug (Nystatin) were used for comparison under similar conditions. DMSO was used as solvent to dissolve the compounds and also used as control. Activity was determined by measuring the diameter of the zone of inhibition in (mm). $200 \mathrm{ml}$ of nutrient agar growth medium was dispensed into sterile conical flasks; these were then inoculated with $20 \mu \mathrm{l}$ of cultures mixed gently and poured into sterile petridish. After setting a borer with $6 \mathrm{~mm}$ diameter was properly sterilized by flaming and used to make three uniform wells in each petridish.

The wells were loaded with $50 \mu$ of different investigated compounds. The solvent DMSO, used for reconstituting the solvent for diluting the compounds, was similarly analyzed for control. The plates were incubated at $37^{\circ} \mathrm{C}$ for 24 hours. The above procedure was also adopted for fungal assays. The used medium was potato dextrose agar and incubated at $27^{\circ} \mathrm{C}$ for 48 hours. The zone of inhibition was measured with a scale in $\mathrm{mm} .{ }^{6}$

\section{DNA cleavage experiment:}

The gel electrophoresis experiments were performed by incubation at $37^{\circ} \mathrm{C}$ for 2 hours as follows: $250 \mathrm{mg}$ of agarose and dissolve it in $25 \mathrm{ml}$ of TAE buffer $(\mathrm{pH}=8.0)$. The samples were electrophoresed for $45 \mathrm{~min}$ at $50 \mathrm{~V}$ on agarose gel using tris-acetic acid-EDTA buffer. After electrophoresis, the gel was stained using with ethidiumbromide (EB) and photographed under UV light.

\section{RESULTS AND DISCUSSION:}

The analytical data for the ligand and the complexes together with some physical properties are summarized in Table 1. The analytical data of the complexes correspond to the general formula [MLX2], where $\mathrm{L}=$ Schiff base hydrazone, $\mathrm{M}$ $=\mathrm{Co}(\mathrm{II}), \mathrm{Ni}(\mathrm{II}), \mathrm{Cu}(\mathrm{II}), \mathrm{Zn}$ (II), $\mathrm{Cd}(\mathrm{II})$ and $\mathrm{Hg}(\mathrm{II}), \mathrm{X}$ $=\mathrm{Cl}^{-}$. The formation of metal (II) complexes may proceed according to the equation given below:

$$
\mathrm{MX}_{2}+\mathrm{L} \rightarrow\left[\mathrm{MLX}_{2}\right]
$$

TABLE: 1 PHYSICAL AND ANALYTICAL DATA OF THE HYDRAZONE SCHIFF BASE AND ITS METAL (II) COMPLEXES

\begin{tabular}{|c|c|c|c|c|c|c|c|c|c|}
\hline \multirow[b]{2}{*}{ Compound } & \multirow[b]{2}{*}{$\begin{array}{l}\text { Molecular } \\
\text { formula }\end{array}$} & \multirow[b]{2}{*}{$\begin{array}{c}\text { Yield } \\
(\%)\end{array}$} & \multicolumn{5}{|c|}{ Found (Calculated) \% } & \multirow{2}{*}{$\begin{array}{c}\Omega \mathrm{m} \\
\left(\Omega^{-1} \mathrm{~cm}^{2}\right. \\
\left.\mathrm{mol}^{-1}\right)\end{array}$} & \multirow{2}{*}{$\begin{array}{c}\mu_{\text {eff }} \\
(\mathbf{B M})\end{array}$} \\
\hline & & & $\mathbf{C}$ & $\mathbf{H}$ & $\mathbf{N}$ & $\mathbf{M}$ & $\mathbf{C l}$ & & \\
\hline Ligand & $\mathrm{C}_{24} \mathrm{H}_{14} \mathrm{~F}_{2} \mathrm{~N}_{6} \mathrm{O}_{2}$ & 79 & $\begin{array}{c}63.16 \\
(68.02)\end{array}$ & $\begin{array}{c}3.09 \\
(3.00)\end{array}$ & $\begin{array}{c}18.41 \\
(18.39)\end{array}$ & - & - & - & - \\
\hline$\left[\mathrm{CoLCl}_{2}\right]$ & $\underset{{ }_{2} \mathrm{CoC}_{24} \mathrm{H}_{14} \mathrm{~N}_{6} \mathrm{O}_{2} \mathrm{Cl}}{ }$ & 71 & $\begin{array}{c}49.17 \\
(49.08)\end{array}$ & $\begin{array}{c}2.41 \\
(2.40)\end{array}$ & $\begin{array}{c}14.34 \\
(14.31)\end{array}$ & $\begin{array}{l}10.05 \\
(9.95)\end{array}$ & $\begin{array}{c}6.04 \\
(5.93)\end{array}$ & 19.33 & 4.95 \\
\hline$\left[\mathrm{NiLCl}_{2}\right]$ & $\underset{{ }_{2} \mathrm{~F}_{2}}{\mathrm{NiC}_{24} \mathrm{H}_{14} \mathrm{~N}_{6} \mathrm{O}_{2} \mathrm{Cl}}$ & 68 & $\begin{array}{c}49.19 \\
(49.03)\end{array}$ & $\begin{array}{c}2.41 \\
(2.38)\end{array}$ & $\begin{array}{c}10.02 \\
(10.00)\end{array}$ & $\begin{array}{l}10.01 \\
(9.88)\end{array}$ & $\begin{array}{c}6.05 \\
(5.77)\end{array}$ & 28.81 & 2.98 \\
\hline$\left[\mathrm{CuLCl}_{2}\right]$ & $\begin{array}{c}\mathrm{CuC}_{24} \mathrm{H}_{14} \mathrm{~N}_{6} \mathrm{O}_{2} \mathrm{C}_{1} \\
{ }_{2} \mathrm{~F}_{2}\end{array}$ & 83 & $\begin{array}{c}48.79 \\
(48.77)\end{array}$ & $\begin{array}{c}2.39 \\
(2.37)\end{array}$ & $\begin{array}{c}14.22 \\
(14.15)\end{array}$ & $\begin{array}{c}10.75 \\
(10.72)\end{array}$ & $\begin{array}{c}6.00 \\
(5.93)\end{array}$ & 20.45 & 2.03 \\
\hline$\left[\mathrm{ZnLCl}_{2}\right]$ & $\begin{array}{c}\mathrm{ZnC}_{24} \mathrm{H}_{14} \mathrm{~N}_{6} \mathrm{O}_{2} \mathrm{C}_{1} \\
{ }_{2} \mathrm{~F}_{2}\end{array}$ & 60 & $\begin{array}{c}48.64 \\
(48.41)\end{array}$ & $\begin{array}{c}2.38 \\
(2.36)\end{array}$ & $\begin{array}{l}14.18 \\
(41.05)\end{array}$ & $\begin{array}{l}11.03 \\
(10.99)\end{array}$ & $\begin{array}{c}5.98 \\
(5.77)\end{array}$ & 17.92 & - \\
\hline$\left[\mathrm{CdLCl}_{2}\right]$ & $\underset{{ }_{2} \mathrm{~F}_{2}}{\mathrm{CdC}_{24} \mathrm{H}_{14} \mathrm{~N}_{6} \mathrm{O}_{2} \mathrm{C}_{1}}$ & 84 & $\begin{array}{c}45.06 \\
(45.01)\end{array}$ & $\begin{array}{c}2.21 \\
(2.19)\end{array}$ & $\begin{array}{l}13.14 \\
(13.00)\end{array}$ & $\begin{array}{l}17.57 \\
(17.39)\end{array}$ & $\begin{array}{c}5.54 \\
(5.44)\end{array}$ & 24.50 & - \\
\hline$\left[\mathrm{HgLCl}_{2}\right]$ & $\begin{array}{c}\mathrm{HgC}_{24} \mathrm{H}_{14} \mathrm{~N}_{6} \mathrm{O}_{2} \mathrm{C} \\
\mathrm{l}_{2} \mathrm{~F}_{2}\end{array}$ & 85 & $\begin{array}{c}39.60 \\
(39.54)\end{array}$ & $\begin{array}{c}1.94 \\
(1.92)\end{array}$ & $\begin{array}{c}11.55 \\
(11.52)\end{array}$ & - & - & 15.11 & - \\
\hline
\end{tabular}

Molar conductance:

Molar conductance of the complexes were measured in DMF at a concentration of $0.001 \mathrm{M}$. The observed conductance values indicating that the complexes are non-electrolyte. ${ }^{8}$

\section{Electronic spectral studies:}

Electronic spectra of $\mathrm{Co}(\mathrm{II}), \mathrm{Ni}$ (II) and $\mathrm{Cu}$ (II) complexes were recorded in DMF medium and spectral bands of the complexes are summarized in Table 2. The Co(II) complex exhibited three bands at 16077 and $21186 \mathrm{~cm}^{-1}$ corresponding to $v_{2}$ and 
$v_{3}$ transitions attributed to $\quad{ }^{4} \mathrm{~T}_{1 \mathrm{~g}}(\mathrm{~F}) \rightarrow{ }^{4} \mathrm{~T}_{2 \mathrm{~g}}(\mathrm{~F})\left(v_{2}\right)$ and ${ }^{4} \mathrm{~T}_{1 \mathrm{~g}}(\mathrm{~F}) \rightarrow{ }^{4} \mathrm{~T}_{2 \mathrm{~g}}(\mathrm{P})\left(v_{3}\right)$. However, $v_{1}$ band is not observed because of its proximity to strong $v_{3}$ transition. Magnetic measurements for the $\mathrm{Co}$ (II) complex has $\mu_{\text {eff }}$ value of $4.51 \mathrm{BM}$.

The three well-separated absorption bands were observed at $\lambda_{\max } \sim 9649, \sim 15479$ and $\sim 25252$ $\mathrm{cm}^{-1}$ which are attributed to the ${ }^{3} \mathrm{~A}_{2 \mathrm{~g}} \rightarrow{ }^{3} \mathrm{~T}_{2 \mathrm{~g}},{ }^{3} \mathrm{~A}_{2 \mathrm{~g}}$ $\rightarrow{ }^{3} \mathrm{~T}_{1 \mathrm{~g}}(\mathrm{~F}), \quad{ }^{3} \mathrm{~A}_{2 \mathrm{~g}} \quad \rightarrow{ }^{3} \mathrm{~T}_{1 \mathrm{~g}}(\mathrm{P})$, transitions respectively, in the spectra of the $\mathrm{Ni}$ (II) suggest the octahedral geometry. The complex shows $\mu_{\text {eff }}$ value of $3.00 \mathrm{BM}$.

The $\mathrm{Cu}(\mathrm{II})$ complexes showed a broad visible band, $\lambda_{\max }$ at $\sim 14285-16949 \mathrm{~cm}^{-1}$ is assignable to ${ }^{2} \mathrm{Eg}_{2} \rightarrow \mathrm{T}_{2 \mathrm{~g}}$ transition. This, together with the measured $\mu_{\text {eff }}$ value of $\sim 1.74 \mathrm{BM}$ suggests the octahedral geometry. ${ }^{9}$

TABLE 2: ELECTRONIC SPECTRAL BANDS AND LIGAND FIELD PARAMETERS OF THE Co(II), Ni(II) AND Cu(II) COMPLEXES IN DMF $\left(10^{-3} \mathrm{M}\right)$ SOLUTION

\begin{tabular}{|c|c|c|c|c|c|c|c|c|c|}
\hline \multirow[b]{2}{*}{ Complexes } & \multicolumn{3}{|c|}{ Transitions in $\mathrm{cm}^{-1}$} & \multirow{2}{*}{$\operatorname{Dq}\left(\mathrm{cm}^{-1}\right)$} & \multirow[b]{2}{*}{$B^{\prime}\left(\mathbf{c m}^{-1}\right)$} & \multirow[b]{2}{*}{$\beta$} & \multirow{2}{*}{$\beta \%$} & \multirow[b]{2}{*}{$v_{2 /} v_{1}$} & \multirow[b]{2}{*}{ LFSE (k cal) } \\
\hline & $\overline{v_{I}}$ & $\overline{v_{2}}$ & $\overline{v_{3}}$ & & & & & & \\
\hline$\left[\mathrm{CoLCl}_{2}\right]$ & 7366 & 16077 & 21186 & 871 & 1010 & 0.97 & 2.78 & 2.18 & 14.93 \\
\hline$\left[\mathrm{NiLCl}_{2}\right]$ & 9649 & 15479 & 25252 & 964 & 785 & 0.75 & 24.46 & 1.60 & 33.08 \\
\hline$\left[\mathrm{CuLCl}_{2}\right]$ & & $4285-169$ & & 1561 & - & - & - & - & 26.77 \\
\hline
\end{tabular}

\section{IR spectral studies:}

The IR spectral data of the hyrazone Schiff base and its metal (II) complexes are presented in Table 3. In the spectrum of the ligand, a band corresponding to the azomethine group $(-\mathrm{HC}=\mathrm{N})$ and $v(\mathrm{C}=\mathrm{O})$ were found at $1577 \mathrm{~cm}^{-1}$ and $1681 \mathrm{~cm}^{-}$ 1 . On complexation, this band shifted to a lower wave number range of $1508-1570 \mathrm{~cm}^{-1}$ and 1650 1676. This indicated the involvement of $\mathrm{N}$-atom of the azomethine $(-\mathrm{HC}=\mathrm{N})$ group and carbonyl oxygen in complex formation ${ }^{10,11}$ and the band at $3207,1606 \mathrm{~cm}^{-1}$ in the spectra of all the complexes were assigned to $v(\mathrm{~N}-\mathrm{H})$ and $v(\mathrm{C}=\mathrm{N})$ of the ketimine moiety remain almost unaffected, indicating the non participation of these groups in coordination. ${ }^{12}$ Therefore, the IR spectral data indicated that the coordination of hydrazone Schiff base to metal ion occurred through the $\mathrm{N}$-atom of the azomethine $(-\mathrm{C}=\mathrm{N})$ group and the $\mathrm{O}$-atom of carbonyl $(\mathrm{C}=\mathrm{O})$ group. Assignment of the proposed coordination sites was further supported by the appearance of medium bands at $453-499 \mathrm{~cm}^{-1}$ and $351-379 \mathrm{~cm}^{-1}$ due to $\mathrm{M}-\mathrm{N}$ and $\mathrm{M}-\mathrm{Cl}$ stretching frequencies, respectively. ${ }^{13,14}$

TABLE 3: IR SPECTRAL BANDS OF THE LIGAND AND ITS METAL COMPLEXES (CM ${ }^{-1}$ )

\begin{tabular}{|c|c|c|c|c|c|c|c|}
\hline $\begin{array}{c}\text { Tentative } \\
\text { assignments }\end{array}$ & $\mathbf{L}$ & {$\left[\mathrm{CoLCl}_{2}\right]$} & {$\left[\mathrm{NiLCl}_{2}\right]$} & {$\left[\mathrm{CuLCl}_{2}\right]$} & {$\left[\mathrm{ZnLCl}_{2}\right]$} & {$\left[\mathrm{CdLCl}_{2}\right]$} & {$\left[\mathrm{HgLCl}_{2}\right]$} \\
\hline Indole ring $\mathrm{NH}$ & 3207 & 3207 & 3207 & 3207 & 3207 & 3207 & 3207 \\
\hline $\mathrm{v}(\mathrm{C}=\mathrm{O})$ ring & 1681 & 1676 & 1668 & 1653 & 1650 & 1673 & 1650 \\
\hline $\mathrm{v}(\mathrm{C}=\mathrm{N}) \operatorname{ring}$ & 1606 & 1606 & 1606 & 1606 & 1606 & 1606 & 1606 \\
\hline $\begin{array}{l}\mathrm{v}(\mathrm{C}=\mathrm{N}) \\
\text { aldemine }\end{array}$ & 1577 & 1530 & 1526 & 1508 & 1567 & 1570 & 1564 \\
\hline $\mathrm{v}(\mathrm{N}-\mathrm{N})$ & 928 & 998 & 1000 & 1024 & 1045 & 1068 & 1077 \\
\hline $\mathrm{v}(\mathrm{M}-\mathrm{N})$ & - & 463 & 474 & 482 & 499 & 453 & 458 \\
\hline $\mathrm{v}(\mathrm{M}-\mathrm{Cl})$ & - & 351 & 356 & 363 & 369 & 372 & 379 \\
\hline
\end{tabular}

\section{Mass spectral studies:}

The mass spectrum of the hydrazone Schiff base shows a molecular ion peak at $\mathrm{m} / \mathrm{z} 456$, which is equivalent to its molecular weight. The mass spectrum of the $\mathrm{Zn}(\mathrm{II})$ complex showed a molecular ion peak at $\mathrm{m} / \mathrm{z} 592$, which is the same as that of the molecular weight of the complex. This supports the suggested structure for the complex.

\section{${ }^{1}$ H-NMR spectral studies:}

The ${ }^{1} \mathrm{H}$ NMR spectrra of the prepared hydrazone Schiff base and its $\mathrm{Zn}$ (II) metal complex were measured and interpreted. The azomethine ($\mathrm{HC}=\mathrm{N}$ ) proton is seen at $8.5 \delta$ (singlet), but in case of $\mathrm{Zn}(\mathrm{II})$ complex the peak was observed at $9.3 \delta$ (singlet). The azomethine proton signal in the spectrum of the corresponding complex is shifted 
downfield compared to the free ligand, suggesting the deshielding of the azomethine group due to the coordination with the metal ion. ${ }^{15}$ The peak appeared at $9.6 \delta$ (singlet) is due to the hydrogen of $-\mathrm{NH}$ in the ligand, but in case of $\mathrm{Zn}$ (II) complex the peak was observed at $9.6 \delta$ (singlet). ${ }^{16}$ The phenyl multiplet is seen at $6.5-7.4 \delta$, but in $\mathrm{Zn}$ (II) complex multiplet is seen at $6.9-7.8 \delta .^{17}$

\section{ESR spectra of $\mathrm{Cu}(\mathrm{II})$ complex:}

The ESR spectrum of $\mathrm{Cu}$ (II) complex offer information of status in studying the metal ion environment. The ESR spectra of complexes have been recorded on $\mathrm{X}$ - band at frequency 9.1 GHZ under the magnetic field strength $3000 \mathrm{G}$ in DMF at room temperature and their $\mathrm{g}_{\|}, \mathrm{g}_{\perp}, \mathrm{g}_{a v}$, and $\mathrm{G}$ values have been calculated. The $\mathrm{g}_{\|}$and $\mathrm{g}_{\perp}$ values were found to be 2.1549 and 2.0387, respectively. The $\mathrm{g}_{a v}$ and $\mathrm{G}$ value were calculated to be 2.0774 and $4.2340 .{ }^{18}$

\section{Powder X-ray diffraction studies:}

In the present study, X-ray diffraction study was carried out using Rigaku $\mathrm{D}_{\max } \mathrm{X}$-ray diffractometer. The X-ray was produced using a sealed tube and the wavelength of X-ray was $0.154 \mathrm{~nm}(\mathrm{Cu} \mathrm{K} \alpha$ radiation). The $\mathrm{X}$-ray was detected using a fast counting detector based on silicon strip technology (Rigaku Lynx Eye detector). X-ray absorption fine structure studies was carried out using a conventional Siefert sealed X-ray tube with Tungsten target operating $20 \mathrm{kV}$ and $40 \mathrm{~mA}$. After this process, the scanning of the X-ray films was completed on Carl-Ziess microdensitometer coupled with computer to convert the data into

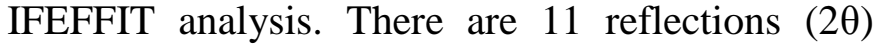
between 4.664 to 68.435 with maxima at $2 \theta=$ 40.648 corresponding to the value of $d=2.217$.

The XRD pattern of the complexes is reported in Fig.2 and data are given in Table 4. The interplanar spacing (d) was analyzed by Bragg's law, $2 \mathrm{~d} \sin \theta=\mathrm{n} \lambda$ and calculated by Debye Scherer's formula. The observed and calculated values of $d$ and are quite consistent. The $\mathrm{h}^{2}+\mathrm{k}^{2}+\mathrm{l}^{2}$ values of the complex were found to be $33,36,56,66,73,81$, $123,133,162,191$. The presence of forbidden numbers 123 and 133 indicates the $\mathrm{Cu}$ (II) complex belongs to hexagonal system. ${ }^{19}$

TABLE 4: X-RAY DIFFRACTION DATA OF Cu(II) COMPLEX

\begin{tabular}{|c|c|c|c|c|c|c|c|c|}
\hline \multirow[b]{2}{*}{$2 \theta$} & \multirow[b]{2}{*}{$\theta$} & \multirow[b]{2}{*}{$\operatorname{Sin} \theta$} & \multirow[b]{2}{*}{$\operatorname{Sin}^{2} \theta$} & \multirow[b]{2}{*}{$h^{2}+k^{2}+l^{2}$} & \multirow[b]{2}{*}{ h k l } & \multicolumn{2}{|c|}{ d Value } & \multirow[b]{2}{*}{ a in $\AA$} \\
\hline & & & & & & Cal & Abs & \\
\hline 4.664 & 2.332 & 0.0406 & 0.0016 & 1 & 100 & 18.9236 & 18.9327 & 18.92 \\
\hline 56.856 & 13.428 & 0.2322 & 0.0539 & $32.5716(33)$ & 522 & 3.3157 & 3.3170 & 18.92 \\
\hline 28.214 & 14.107 & 0.2437 & 0.0594 & $35.8804(36)$ & 600 & 3.1591 & 3.1604 & 18.92 \\
\hline 35.507 & 17.753 & 0.3049 & 0.0929 & $56.1573(56)$ & 642 & 2.5252 & 2.5261 & 18.92 \\
\hline 38.576 & 19.288 & 0.3303 & 0.1091 & 65.9005 (66) & 554 & 2.3310 & 2.3320 & 18.92 \\
\hline 40.648 & 20.324 & 0.3473 & 0.1206 & $72.8632(73)$ & 661 & 2.2619 & 2.2177 & 18.92 \\
\hline 42.881 & 21.4405 & 0.3655 & 0.1336 & $80.7022(81)$ & 900 & 2.1065 & 2.0173 & 18.92 \\
\hline 53.736 & 26.868 & 0.4519 & 0.2042 & $123.3624(123)$ & - & 1.7037 & 1.7044 & 18.92 \\
\hline 56.014 & 28.007 & 0.4695 & 0.2205 & $133.1821(133)$ & - & 1.6397 & 1.6404 & 18.92 \\
\hline 62.284 & 31.142 & 0.5171 & 0.2674 & $161.5397(162)$ & 990 & 1.4888 & 1.4894 & 18.92 \\
\hline 68.435 & 34.217 & 0.5623 & 0.3162 & $190.9940(191)$ & - & 1.3692 & 1.3698 & 18.92 \\
\hline
\end{tabular}

\section{Antimicrobial evaluation of ligand and its metal complexes:}

The ligand and its metal complexes was examined for antimicrobial assay against three bacterial and three fungal strain using the well diffusion method. The values of the tested compounds are shown in Table 5. It was observed from these studies that metal chelates had a higher activity than the free ligand against both bacterial and fungal strains. The complexes $\mathrm{Zn}$ (II) and $\mathrm{Hg}$ (II) exhibited significant antibacterial activity against all bacterial strains. These complexes also exhibited profound activity against all fungal strains. 
TABLE 5: THE ANTIMICROBIAL ACTIVITY OF LIGAND AND ITS METAL (II) COMPLEXES EVALUATED BY (MM).

\begin{tabular}{|c|c|c|c|c|c|c|}
\hline \multirow[b]{3}{*}{ Compounds } & \multicolumn{6}{|c|}{ Zone of inhibition in $\mathbf{~ m m}$} \\
\hline & \multicolumn{3}{|c|}{ Antibacterial activity } & \multicolumn{3}{|c|}{ Antifungal acivity } \\
\hline & $\begin{array}{c}\text { Micrococcus } \\
\text { luteus }\end{array}$ & $\begin{array}{l}\text { Shigella } \\
\text { flexneri, }\end{array}$ & $\begin{array}{c}\text { Enterococcus } \\
\text { aerogens }\end{array}$ & $\begin{array}{l}\text { Candida } \\
\text { krusiae }\end{array}$ & $\begin{array}{c}\text { Candida } \\
\text { parasilopsis }\end{array}$ & $\begin{array}{c}\text { Malassesia } \\
\text { pachydermatis }\end{array}$ \\
\hline $\mathrm{L}$ & 12 & 8 & 14 & 7 & 13 & 10 \\
\hline$\left[\mathrm{CoLCl}_{2}\right]$ & 20 & 25 & 22 & 28 & 19 & 17 \\
\hline$\left[\mathrm{NiLCl}_{2}\right]$ & 19 & 28 & 16 & 15 & 21 & 26 \\
\hline$\left[\mathrm{CuLCl}_{2}\right]$ & 18 & 20 & 26 & 18 & 27 & 23 \\
\hline$\left[\mathrm{ZnLCl}_{2}\right]$ & 35 & 33 & 28 & 34 & 36 & 30 \\
\hline$\left[\mathrm{CdLCl}_{2}\right]$ & 22 & 28 & 20 & 30 & 25 & 21 \\
\hline$\left[\mathrm{HgLCl}_{2}\right]$ & 33 & 30 & 26 & 35 & 37 & 29 \\
\hline Ampicillin & 40 & 36 & 32 & - & - & - \\
\hline Nystatin & - & - & - & 39 & 42 & 34 \\
\hline
\end{tabular}

\section{DNA cleavage efficiency:}

The degree to which the five complexes could function as DNA cleavage agents was examined using Calf-thymus DNA as the target. The efficiency of cleavage of these molecules was probed using agarose gel electrophoresis. ${ }^{20}$ DNA cleavage activity of prepared compounds (Co(II), $\mathrm{Ni}(\mathrm{II}), \mathrm{Cu}$ (II), Cd(II), Zn(II) and $\mathrm{Hg}$ (II) (lanes SA ${ }^{-}$
$\mathrm{SA}_{6}$ respectively)) were analyzed by monitoring the conversion of supercoiled DNA (Form I) to nicked DNA (Form II) and linear DNA (Form III). SA 4 has displayed partial cleavage of DNA and all the other samples have shown complete cleavage of DNA (Fig. 3). ${ }^{21}$

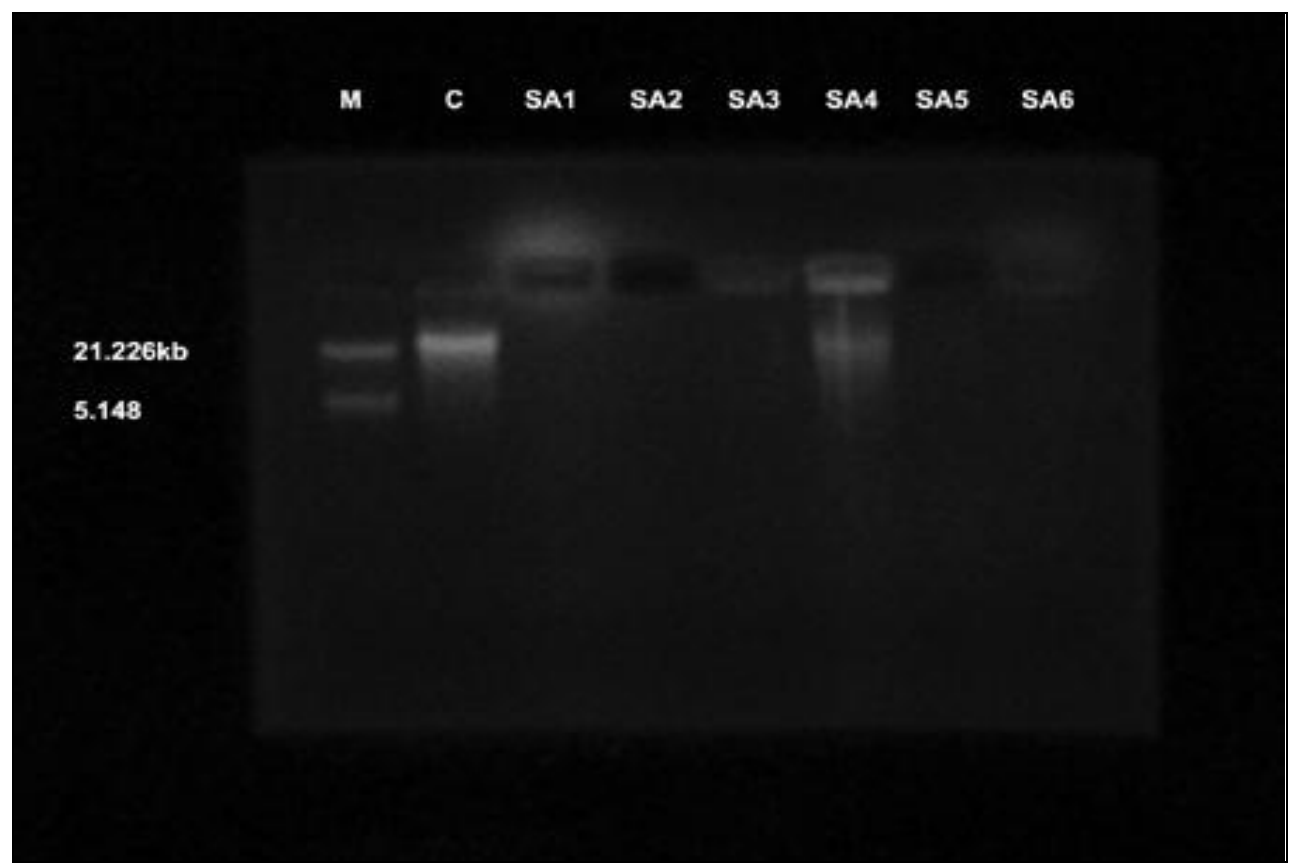

FIG. 3: GEL PICTURE SHOWING THE CLEAVAGE ANALYSIS OF SAMPLES

CONCLUSION: In this paper, the preparation, physico-chemical investigations and biological Screening of hydrazone Schiff base and its metal (II) complexes were reported. The complexes were formed in 1:1 (metal:ligand) ratio, as confirmed by the spectral analysis. The results of different analytical and spectroscopic analyses revealed that the complexes have octahedral geometry (Fig. 4). The hydrazone Schiff base acts as a tetradentate ligand and binds to metal ions through the carbonyl oxygen and the azomethine nitrogen. The Microbial activity of the ligand and its complexes have been studied on three bacterial, Micrococcus luteus, Shigella flexneri, Enterococcus aerogens and three fungal strains Candida krusiae, Candida parasilopsis and Malassesia pachydermatis by well Fusion method and found that the metal complexes are more active on microorganisms than the 
hydrazone Schiff base ligand. The DNA cleavage activity of the metal (II) complexes showed good DNA cleavage efficiency.

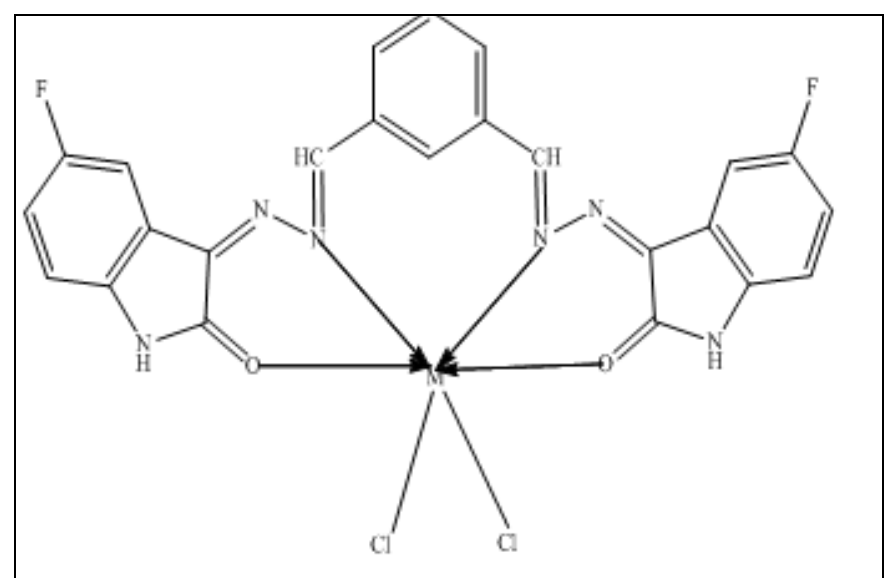

FIG. 4: PROPOSED STRUCTURE OF M =Co(II), Ni(II), $\mathrm{Cu}(\mathrm{II}), \mathrm{Zn}(\mathrm{II}), \mathrm{Cd}$ (II) AND Hg(II) METAL COMPLEXES

ACKNOWLEDGEMENT: The authors are thankful to the Chairman, Department of Chemistry, Gulbarga University, Gulbarga, for encouragement and facilities. One of the authors (NSM) is thankful to UGC New Delhi for the grant of research fellowship in science for Minority students Under MANF Scheme. We are also thankful to IIT Chennai, IIT Bombay and STIC Cochin for providing Spectral data.

\section{REFERENCES:}

1. Ahmed M, Abu-El-Halawa R, Zabin SA, Ibrahim M, AlRefai $M$ and Tawfeq K: Synthesis, characterization and antifungal activity of some metal complexes derived from quinoxaloylhydrazone. World Journal of Organic Chemistry 2015; 3:1-8.

2. Priya S, Senthil kumaran J, Jayachandramani N and Mahalakshmi S: Antibacterial studies of transition of tetradentate thiazole based Schiff base. American Journal of Pharm Tech Research 2013; 3:607-616.

3. Chaisab K. Bhkahk and Jabbar S. H: New unsymmetrical Schiff base as inhibitor of carbon steel corrosion and antibacterial activity. Research Journal of Chemical Sciences 2015; 5:64-70.

4. Vogel A I: A Text book of quantitative inorganic analysis, $3^{\text {rd }}$ Edn.; Longman: London 1962.

5. Odds F C: Antifungal activity of saperconazole (R 66 905) in vitro. Journal of Antimicrobial Chemotherapy 1989; 24: 533-537.

6. Anjali J, Murthy YLN and Durga G: Synthesis, characterization and bioactivity of transition metal complexes of new 3-methyl-5-mercapto-4-triazole Schiff bases. Research Journal of Pharmaceutical, Biological and Chemical Sciences 2015; 6: 1306- 1314.

7. Sambrook J, Fritsch E F and Maniatis T: Molecular Cloning, A Laboratory Manual, $2^{\text {nd }}$ ed., Cold Spring
Harbor Laboratory, Cold Spring Harbor, New York 1989.

8. Geary W J: The use of conductivity measurements in organic solvents for the characterization of coordination compounds. Coordination Chemistry Reviews 1971; 71: $81-122$.

9. Joshi K C, Pathak V K. Metal chelates of fluorinated 1,3-diketones and related compounds. Coordination Chemistry Reviews 1977; 22: 37-122.

10. Siddappa $\mathrm{K}$ and Nabiya sultana $\mathrm{M}$ : Synthesis, spectroscopic characterization, and biological evaluation studies of 5-Bromo-3-(((hydroxy-2methylquinolin-7-yl)methylene)hydrazono)indolin-2one and its metal (II) complexes. Bioinorganic Chemistry and Applications 2014; 1-11.

11. Padmaja M, Gyana Kumari C and Rajesh R: Synthesis, characterization, DNA Binding, DNA cleavage and antimicrobial studies of Schiff base ligand and its metal complexes. Journal of Fluorescence 2015; 25: 69-378.

12. Siddappa $K$, and Nabiya sultana $M$ : Synthesis, spectroscopic characterization and biological evaluation studies of Schiff base derived from 5-bromo-3hydrazonoindolin-2-one with 5,5dimethylcyclohexane-1,3-dione and its metal complexes. International Journal of Research in Chemistry and Environment. 2014; 4: 78-84.

13. Balamurugan $\mathrm{V}$ and Shankar S: Synthesis, characterization and biological studies of nano sized metal complexes of $\mathrm{Fe}(\mathrm{II}), \mathrm{Co}(\mathrm{II})$ and $\mathrm{Cr}(\mathrm{II})$ with $\mathrm{N}, \mathrm{N}$ ' -bis(benzoin)-1,4 butane diimine. International Journal of Pharmaceutical Science Review and Research 2015; 31: 54-57.

14. Siddappa K and Nabiya sultana M: Synthesis, structural characterization, antimicrobial activity and DNA cleavage of transition metal (II) complexes derived from 5-bromo-3-hydrazonoindolin-2-one, 3-((2aminoethyl) amino) quinoxalin-2(1H)-one and 2,2dimethyl-1,3-dioxane-4,6-dione. International Journal of Current Research 2015; 7: 11349-11354.

15. Nasir Uddin M, Abdus Salam M and Jannat Sultana: $\mathrm{Pb}$ (II) complexes of Schiff bases derived from benzoylhydrazine as the antibacterial agents. Modern Chemistry 2015; 3: 7-14.

16. Ajith Sinthuja S: Antimicrobial screening of novel Schiff base Ni(II) complex derived from glutaraldehyde and L-histidine. The International Journal of Science and Technoledge 2015; $3: 238-242$.

17. Martina M K, Tomislav B, Berislav M and Anamarija $\mathrm{S}$ : Comparison of the electrochemical properties of two structurally different novel bis-Schiff bases. International Journal of electrochemical science 2015; 10: $63-83$.

18. Veerappan Subramanian S M, Narayanasamy R and Balachandran K: Synthesis of mononuclear Schiff base $\mathrm{Cu}(\mathrm{II}), \mathrm{Ni}(\mathrm{II}), \mathrm{Co}(\mathrm{II})$ and $\mathrm{Mn}(\mathrm{II})$ complexes and their application for DNA cleavage and antibacterial agent. Chemical Science Review and Letters 2015; 4: 121 128.

19. Mishra A, Yadav A, Ninama S and Trivedi A: EXAFS and XRD studies of copper and cobalt complexes of amino acid. International Conference on Recent Trends in Physics 2012; 1-4. 
20. Shiva Kumar L, Shiva Prasad K and Doddarevanna Revanasiddappa H: Synthesis, characterization, antioxidant, antimicrobial, DNA binding and cleavage studies of mononuclear $\mathrm{Cu}$ (II) and $\mathrm{Co}$ (II) complexes of 3-hydroxy- $N$ '-(2-hydroxybenzylidene)-2-naphthohydraz id. European Journal of Chemistry 2011; 2: 394-403.
21. Hitendra Kumar L, Taibi Ben H, Snigdha D and Ajai Kumar P: Biological evaluation of inhibitors of reverse transcriptase from HIV type-1. Current Chemistry Letters 2015, 4: 7-20.

\section{How to cite this article:}

Siddappa K and Sultana MN: Synthesis, Physico-Chemical Investigations and Biological Screening of Metal (Ii) Complexes with Hydrazone Schiff Base Derived From 5-Fluoro-3-Hydrazonoindolin-2-One and Isophthalaldehyde. Int J Pharm Sci Res 2016; 7(1): 236-43.doi: 10.13040/IJPSR.0975-8232.7(1).236-43.

All @ 2013 are reserved by International Journal of Pharmaceutical Sciences and Research. This Journal licensed under a Creative Commons Attribution-NonCommercial-ShareAlike 3.0 Unported License.

This article can be downloaded to ANDROID OS based mobile. Scan QR Code using Code/Bar Scanner from your mobile. (Scanners are available on Google Playstore) 